\title{
Mentoring Young People in Veeplaas Seventh-day Adventist Church: The Role of the Local Church Leadership
}

\author{
Bulelani Bomela \\ Adventist University of Africa, Kenya
}

\begin{abstract}
Youth Ministries is the lifeblood of the Church today. This ministry is also designed to assist youth within and youth in the communities. The Seventh day Adventist World Church membership is mainly composed of young people with an estimate of $75 \%$. Young people have been and continue to take leadership roles in the local church. Yet, the Church's challenge of losing young people and failure to uphold Christian standards has been discovered to be increasing day by day. The degrading standards and morals within church youth hinder one of Adventist youth Ministries' objectives, which is 'Youth working for other youth.' It is further discovered that the neglect of mentoring programmes which provide opportunities for youth to develop spiritually and mentally and the absence of spiritual and mentally matured mentors in the local churches is the cause for either the loss of young people or poor decision making by youth in matters relating to life. This article seeks to discover and display the use of mentorship programs at Veeplaas church of Seventh day Adventist as means to retain youth, reduce or prevent moral degeneration and providing counseling and guidance among them. Literature is used to review, define and critically look at mentoring as a discipline effective for youth development.
\end{abstract}

NB: Unless otherwise stated, all biblical quotations would be from the New King James Version of the Bible.

\section{INTRODUCTION}

\section{Background of the Study}

A ccording to the Cape Conference Sabbath School count records, almost every Sabbath in the local churches within its territory half the church consists of youth attendees. This is an indication that the church is young as the bulk of percentage is young people ages 0-35 according to the Cape Conference Secretariat department. The fact that the church is mostly made up of young people is commendable, however, it should also be considered that these young people come to church by either their own volition or coerced by their parents or adults who stay with them.. This scenario has been evident in South Africa, particularly in Port Elizabeth, where Veeplaas Church is situated, during the lockdowns due to the pandemic, where most young people have not yet managed to return to church. In South Africa even at alert level 1 of the Disaster management, some choose to stay home, while some get busy with their business in shopping malls or entertaining activities.
There is a noticeable alarming wave these days of some young people are involved in unacceptable behaviours during the week. Such alarming behaviour escalates and worsens during weekend. The observation is that these behaviours include drinking liquor, use of drugs, less or no respect for adults and sexual promiscuity. This rampant misbehaviour of young people, in my view, is either caused by choices young people make, peer pressure, for some retaliation because anger toward parents, lack of good parenting, poor local church planning and strategies, visionary leadership and absent spiritual and mentally matured teachers and mentors at local church. These reasons may be the cause for the misbehaving and unruly conducts we see in our youth today. A question needs to be asked 'what then can be done to resolve, to contain and to subvert these behaviours? This paper will seek to suggest a solution to the local church, schools around Zwide in Port Elizabeth and homes where these young people come from, in resolving the situation painted above. I will seek to introduce Mentoring Young People in Veeplaas Seventh-day Adventist Church: The Role of the Local Leadership as a vehicle that brings transformation of minds which translates to and transformation of behaviours. There is a call on local Leadership to focus resources and energy to assisting young people with mental, physical and spiritual development as part of the mentoring programme. We will define Mentorship as a concept to assist an upcoming and unearthing a potential. We will further present a biblical view and examples of mentorship; give roles of mentors (focusing on Veeplaas Seventh-day Adventist Church).

\section{What is Mentorship?}

Scholars have written on mentorship, looking at different aspects of mentorship, for the purposes of this paper mentorship will be defined. A historical definition of mentoring from Homer's Odyssey is provided by Herman (2004) and Steinman (2006), defining mentoring as

the process where a person with a serving and inspirational attitude (mentor) firstly sees the development and leadership potential in a still-to-bedeveloped person (the mentee/protégé). Mentoring is thus viewed as a dynamic, shared, personal relationship in which the more experienced person acts as advisor, 
guide and role model for a less experienced person (the protégé). ${ }^{1}$

Definition The meaning of the word mentor refers to someone who is a 'father figure,' who sponsors, guides and develops a younger person. Earl agrees by stating that "mentoring is the empowering of one person by another through personal life, prayer, conversation, and example. It is making disciples to go into the entire world who will in turn reproduce others to do the same." ${ }^{2}$ Notice that the above definition touches more on faith based mentorship. Stanley and Clinton "mentoring is a relational experience in which one person empowers another by sharing God given resources." 3 Another faith-based development through mentorship is defined by Mallison as "dynamic relationship of trust in which one person enables other to maximize the grace of God in his/her life and service." ${ }^{4}$ In this definition one sees the commitment to enable and to allow another person to develop through guidance. Meyer and Fourie have purposed that "mentoring can be described as a dynamic and reciprocal relationship in a work environment whereby a more advanced and wiser incumbent (mentor) helps a less experienced person who has developmental potential (mentee who is not his direct subordinate) develops in one specific capacity." 5 This definition puts a strong emphasis on the dynamic reciprocal relationship between a mentor and a mentee. As a Pastor who works with young people, I can attest that throughout history mentors have played a significant role in developing mentees through teaching, inducting someone into new life and skills. To count but a few Moses mentored Joshua (see Duet 31:1-8; 34:9), Eli mentored Samuel (see 1 Sam 3), Paul mentored Timothy (see 2Tim 2). There is a vast biography of mentors who have helped mentees to develop skills. In elaborating the objective behind mentoring Crosby has defined "Mentoring as a brain to pick, and ear to listen and a push to the right direction." ${ }^{\circ}$ Those who must work with young people must have according to Crosby an ear to listen while attempting to challenge the brain as they lead the mentee to the right direction. Mentorship programmes involve two people whose function is not the same. Mentorship is a leadership skill possession and capacity which is "described as reciprocal and collaborative learning relationship between two individuals...."7 Mentoring and skillful coaching can be used

\footnotetext{
${ }^{1}$ L. Herman, from teaching to mentoring: Principle and Practice, dialogue and life in adult education (London: Routledge Falmer), 2004, 3.

N. Steinmann, Fundamentals for Effective Mentoring: Raising giant killers (Randburg, South Africa: Knowres Publishing), 2006. 3.

${ }^{2}$ P. Earl, Mentoring. Renewal Journal. Discipleship, 11. Retrieved December 5, 2007, from www. pastornet.au

${ }^{3}$ P.D., Stanley and Clinton, R.C. Connecting: The Mentoring Relationship you need to succeed in life (Colorado Springs: Navpress), 1992, 33

${ }^{4} \mathrm{~J}$. Mallison, Mentoring to develop disciples and leaders (Buckinghamshire, UK: Scripture Union, 1998),

${ }^{5}$ M. Meyer, and Fourie, L. Mentoring and Coaching: Tools and Techniques for implementation (Randburg, South Africa: Knowres Publishing, 2004), 2

${ }^{6}$ John C. Crosby “On the Importance of Mentorship," Accessed 18 July 2019, http://www.healio.com/journals/ortho/2009-4-32-4/\%7B3b54a1b2-a9fa-4d46a6c2-a517f8b2dcb4\%7D/on- the-importance-of-mentorship.

${ }^{7}$ L.J. Zachary, Creating Mentoring Culture: The Organizations Guide (San Francisco, Jossey-Bass, 2005), 3.
}

interchangeable. The joy and the success of mentoring someone rest on the positive relationship of the two individuals. Crawford defines this relationship "as a caring and supportive interpersonal relationship between someone experienced and knowledgeable and someone less experienced and knowledgeable." ${ }^{8}$ Common to both the mentor and mentee are the issues relating to sharing ideas and knowledge. It is highly possible that someone may be experienced and knowledgeable but lacking to display the knowledge and experience through a day-to-day life. Learning which translates to growth becomes the key point in mentoring, as "mentoring is a relationship where two people are committed to learning, to growth and to each other." Mentees seem to also learn by observing the steps of a mentor. Holiday argues that "mentoring does not only involves what is taught verbally but a mentor also teaches by example." ${ }^{10}$ This notion encourages mentors to live a life that is exemplary because trusted actions are as good as trusted words. Mentors words must correspond with his/her actions.

\section{HISTORY OF MENTORING}

Blackeslee et al advocates that matching young people with adults is one of the oldest strategies employed in community based- interventions and these strategies are used to prevent youth problem behaviours and promote positive youth development. ${ }^{11}$ Kram highlights that traditional or informal mentoring arrangements continue to operate in context where the mentor and the mentee somehow find each other. ${ }^{12} \mathrm{I}$ have observed that the application of these strategies of matching young with experience in African culture, has proved over years to be effective and many have benefitted as character foundations were built. As a pastor who ministered in multi cultural and multi national settings, it has been my experience that these strategies spread over throughout various cultural backgrounds. Within the African culture they were used as means to develop and equip a boy with information and knowledge of in a range of areas like adulthood and manhood, academics and social well-being which would include respect for other man and adults, prevention of risky behaviours and building mental health. ${ }^{13}$ The Xhosa ceremony of intonjane, an initiation for girls afforded an opportunity for them to be trained and prepared for womanhood and sometimes even marriage, prevention from risky behaviors like falling pregnant and taking care of girl responsibilities.

\footnotetext{
${ }^{8}$ C.J. Crawford, Manager's Guide to Mentoring (Madison, WI: CWL Publishing, 2010), 7.

9 W.C. Write, Mentoring: The Promise of Relational Leadership (Waynesboro, GA: Paternoster Press, 2004), 137.

${ }^{10} M$. Holiday, Coaching, Mentoring and Managing, $2^{\text {nd }}$ ed. (White Plains, NY: Career Press, 2001), 5.

${ }^{11}$ Blakeslee, Jennifer E. and Keller, Thomas E. "Mentoring: Building the Youth Mentoring Knowledge Base: Publishing Trends and Coauthorship Networks," Journal of Community Psychology Vol. 40 (September 2012): 845-859, accessed 17 July 2019, http://dx.doi.org /DOI: 10. 1002/jcop.21494, Accession Number 78333656

12 K.E. Kram, Mentoring at Work: Developmental Relationships in Organizational Life (Glenview, IL: Scott Foresman, 1985),

13 J.S. Mbiti, African Religions and Philosophy, $2^{\text {nd }}$ Ed. (Heinemann Educational Publishers, 1969),
} 


\section{BIBLICAL VIEWS AND EXAMPLES ON MENTORING}

The word mentor is not found in the bible. However, noticed are the relationships between individuals, which depict a definition, establishment of mentoring which is aimed at changing life. Moore correctly states that "those impacted by mentoring were life- changers and some became world impacters!" ${ }^{\prime 4}$ Mentoring young people as a way of solidifying foundations of doctrine, Christian living and character is a biblical mandate (see Prov 22:6 and Deut 6: 4-9). ). Ellen White implies on her definition of education that the schools of prophets were designed to mentor students as a way of harmoniously developing them "spiritually, physically and mentally." ${ }^{15}$ This work was also performed by parents (Patriarchs), teachers in the schools of prophets, priests and prophets. This was done to lay a good foundation of biblical faith in God and to preserve the culture, values and principles of Israel as a nation. Some of these key mentoring relationships within Israel as a nation were Jethro with Moses (Exod 18,; Moses with Joshua (Deut 3:28,31:1-8, Moses with Caleb (Num 13:6, Naomi with Ruth (Ruth 1-4, Samuel with Saul (1Sam 9-15, Mordecai with Esther (Esth 1-10). The approaches cited above were different as per scenario as mentoring was done to lay a good foundation of biblical faith in God, in some instances to preserve the culture, values and principles of Israel as a nation, leadership development and building character. In Proverbs 22:6, which depicts biblical mentorship, the writer sums up mentorship as training up a Child in the way he should go, and when he is old he will not depart from it. The schools of the prophets are located in the Old Testament and it appears that their main purpose was to mentor young people. Psalms 71:18, (NKJV) "Now also when I am old and grey headed, Oh God, do not forsake me, until I declare your strength to the generations, your power to everyone who is to come," suggests that senior mentors have a responsibility to mentor the upcoming generations.

These were building a firm foundation that would see its fruits in the future endeavors. In the History of the Bible, Daniel, Shadrack, Meshack and Abednego demonstrated strong faith in God when they were tested in Babylon by King Nebuchadnezzar to worship foreign gods. The skillful, meticulous approach to matters of governance and integrity within the government of Babylon could only refer back to the foundation built through careful mentoring by church leaders back in Jerusalem, as referenced in the story of Joseph, Gen 39.

Joseph's response to Potiphar's wife in Genesis 39:9 “ ....How then can I do this great wickedness, and sin against God?" The text quoted above is an indication and a display of firm foundation which his father Jacob instilled while a young boy. Jacob took time to train the young lad while the mind was still fresh and receptive, and White explains, "in his

\footnotetext{
${ }^{14}$ W.B. Moore, Mentoring side by side: Mentoring in the Bible. Retrieved 5 December 2007, from www.mentoring-disciples .org

${ }^{15}$ E.G. White, Education (Mountain View, CA: Pacific Press, 1903), 13
}

childhood he had been taught to love and fear Him (God)." 16 His stance on principle matter did not require the presence of a mentor in Egypt, but the level and the standard of education he received at home carried him through. In the face of predicament White argues, "then his thoughts turned to father's God." ${ }^{17}$ What seems to be highlighted by White in the previous quotation is that the turning to his father's God indicates the type of mentoring lessons he had received from the father at an early age. The lessons he received laid a firm foundation for decision-making in time of crisis.

In the New Testament Paul was responsible for Timothy's growth and maturity in Ministry, he bade him to follow biblical statutes (see 2 Tim 2:15). Timothy's success and endurance in ministry is founded on the encouragements, admonitions and nurturing skills of Paul as a mentor. Paul's relationship with Timothy is one excellent example of him teaching his son to imitate him. Baker and Rathkamp have called this relationship between the two as a "JPT relationship." ${ }^{18}$ The JPT stands for Jesus, Paul and Timothy, taken from Paul's statement "Imitate me as I imitate Jesus (see 1 Cor 4:16). It is my view that sons imitate their fathers in general.

Finally Jesus mentored his disciples for a period of three and half year before he could mandate them to go and advance the gospel. Jesus used parables and challenging everyday experiences to educate them for future ministry. In Matthew 11:29 the words Jesus uttered " and learn of Me" are a vital point departure towards mentoring disciples and believers for the entire ministry application. He regarded his disciples and believers as children who must still be taken through a process of growth, physically, mentally and spiritually. Through contact with Jesus, Harrison explains: "that the twelve almost unconsciously absorbed from him. They must have learnt something about the art of meeting people and handling situations as they witnessed their Master threading his way through life with its maze of difficult circumstances occasioned by the public character of his work. ${ }^{" 19}$ One of the best ways of maintaining this similar strategy of Jesus in preparing young people is for faithful leaders and mentors bringing them into mentoring relationship in a local church context.

\section{THE ROLE OF CHURCH LEADERSHIP IN MENTORING YOUTH}

Churches these days are in dire state and "nobody knows better than pastors the critical shortage of leaders in the Church today and worldly encroachments into the existing

\footnotetext{
${ }^{16}$ E.G. White, Patriarchs and Prophets (Washington, DC: Review and Herald, 1890), 213.

${ }^{17}$ E.G. White, Patriarchs and Prophets (Washington, DC: Review and Herald, 1890), 213.

18 Jay Baker and Rathkamp Dave, "Imitate Me": From Paul to Timothy to Today: The Timeless Model for Spiritual Reproduction (Ohio: CreateSpace Independent, 2012), 2.

${ }^{19}$ E.F. Harrison, A Short Life of Christ (Grand Rapids: Zondervan, 1968), 143.
} 
leadership." ${ }^{20}$ The Church would have long seen many decisions and maintained relationships with Jesus by young people if only youth leaders were visionary and caring. The crisis we see in the local churches exists because young people are left to swim on their own, or they sink. It is of vital importance that the pastor, nominating committee elects into Youth Ministry position men and women whom Professor Allan Coppedge say they possess three essential principles which are "life to life transference, spiritual disciplines, and accountability." ${ }^{21}$ Life transference occurs when the mentor shares wisdom, knowledge, experience, and maturity with the mentee in unstructured setting. This is a life of demonstration by the mentor. These mentors, because of their spiritual connection possess a strong relationship with God and finally are accountable to God whom they serve by assisting a young life.

It is therefore the role of the church's committee to look for such leaders, who will lead with diligence and drawing youth to a saving relationship with God and embracing the call to discipleship.

\section{A Need for Healthy Leaders}

An effective church is one that possesses healthy leaders. Leadership strategies are born out of healthy leaders. Most churches lack planning capabilities as a result programs are not energizing. Young people find it difficult to endure boredom. Either they will stay in the church and create their own ways of entertainment, which most of the time are in contravention with church principles. While at church they will continue playing games, listening to worldly entertaining music and surfing net in their smart phones. Others decide to do church hopping which does not sustain their spiritual growth, while some will simple leave church totally. It is therefore imperative that church starts a process of looking into choosing and developing healthy leaders who are burdened by the state our young people find themselves in. Their approach is born out of love for children and young people. The church should settle for those who love youth, as "It is fashionable today to believe that we should not settle for anything less than doing what we love to do." ${ }^{, 2}$ Election into leading young people does not all of a sudden make one exude love for them, but love for them needs no election but passion. It is important to therefore for the church to focus on passion, love and spiritual healthy youth leaders than to be confined to election. Election brings about babysitters and love for youth brings about parenting.

\footnotetext{
${ }^{20}$ Ted W. Engstrom and Norman B. Rohrer, The Fine Art of Mentoring: Passing on to Others What God Has Given to You (Tennessee: Wolgemuth and Hyatt, 1989), 70.

${ }^{21}$ A. Coppedge, The Biblical Principles of Discipleship (Grand Rapids: Francis Asbury Press, 1989), 61.

${ }^{22}$ Stephen C. Lundin, Harry Paul and John Christensen, Fish! A Remarkable Way to Boost Moral and Improve Results (London: Hodder and Stoughton, 2000), 11.
}

\section{D6 Model}

"D6" is short for Deuteronomy 6. This approach involves integrating leadership from both church and home to disciple current and future generations. This approach views the Church as the "theological anchor, training ground, and resource center for discipleship. ${ }^{23}$ There is a need for the Church to provide echoing voices to speak and show the truth in the lives of young people. Therefore, leaders who have a potential to do that are the most needed and eligible for election to lead and mentor young people.

\section{Benefits for Mentoring Young People}

Children's minds are like a sponge, with capacity to suck and store information that affects them positively or negatively as they grow. As they grow, their minds need to be closely nurtured and guided by either parents, family, as "mentoring programs are not a substitute for a caring family" ${ }^{24}$ and trained mentors. Benefits of mentoring young people outweigh the challenges they face in their day to day living. Mentoring is a practical (as opposed to theory) way of advising, encouraging and supporting a mentee in the journey of life. Mentoring is the very foundation for youth to be able to deal with challenges and live an acceptable life according to the norms, values and beliefs of a particular community. Among the many benefits, I will look at the following: To be firm in decision-making, identifying goals, establishing a sense of direction and ability to handle and be integrated into social life, spiritual development, and embracing a call to discipleship within the believing community. These benefits are more inclined to the mentee rather than the mentor.

\section{Potential Behavioural Benefits}

Mentoring is one component of a programme that involves other elements, such as tutoring or life skills training and even coaching. Whether it is in the form of tutoring, training or even coaching, mentoring establishes a relationship between a mentor and a mentee. The quality of relationship that is established between a mentor and mentee are immediate and long term and mostly contribute to a host of benefits especially for mentees. Cavell et al. argues, "Mentoring relationships are among the most significant relationships that children develop with non-parental figures." 25 This relationship form bases for success in the process with a goal to change through influencing someone's life.

Life's trajectory is long and tedious but can be a short one as well if preparations are not in place. It throws stones to each individual traveller. A shield of protection is therefore a need to avoid hurt and unnecessary injuries. Good mentors are

\footnotetext{
${ }^{23}$ Fernando Arzola et al., Youth Ministry in the $21^{\text {st }}$ Century: Five Views (Grand Rapids: Baker Academic, 2015), 148.

${ }^{24}$ J.E. Rhodes, "Youth Mentoring in Perspective," accessed 18 January 2016, http://www.infield.org/learningmentors/youth_mentoring perspective.htm.

${ }^{25}$ Cavell at al. (2002) The Natural Mentors of adolescent children of alcoholics (COAs): Implications for Perspective Practice. The Journal of Primary Prevention, 23,23-42. doi: 10.1023/A: 1016587115454.
} 
providers of such shields of protection in the form of equipping for survival in life socially. Mentoring is a conduit for achieving objectives like transformation of personal attitudes, decision-making, dealing with at risk behaviours and many more. What affects a young person has a potential of affecting the whole society. Each society demands adherence to its norms, values and principles. Life lived within that society demands from youth well-balanced minds, which will produce high self-esteem and confidence. Mentoring provisions for young people therefore require patience and love for youth builds foundations that can never be shaken, if shaken but cannot move. Mentored youth is equipped youth and is able to stand on its both feet and face life with all vigor and purpose. Good and proper decision making, emotional maturity and discernment becomes the order of the day.

\section{Spiritual Life Development}

There is a strong desire from parents and Church to see young people grow in faith. This desire is driven by a search to see young people connecting with the Saviour in many ways. Young people need affirmation and encouragement from someone who believes in them. Paul says, "Therefore encourage one another and build one another up, just as you are doing" (see 1 Thess 5:11). While a change in one's behaviour is the work of God, it seems Paul is suggesting that a change and growth in one's spiritual life also needs a visible someone who will be an epitome of Christian living to young people. Of the many ways to influence a young person $t$ change is life for the better is mentoring programmes. Purposeful and planned mentorship programmes afford young people an opportunity to read their Bibles regularly, live a prayerful life and transferring spiritual experiences to next generations. Mentorship provides youth with Biblical doctrinal foundation and sane theological ideas. Mentorship "encourages youth to run for the prize (see Phil.3: 14) and help them rid themselves of anything that might slow them (see Heb.12: 1-2)." ${ }^{26}$ Focus in a spiritual walk is pivotal as there may be strong detractors on one's journey. So, we can conclude and say, mentorship programmes have a potential of aligning young people's worldview with God, helping them grow spiritually and focusing on their godly goals.

\section{Discovering and Embracing Spiritual Gifts}

One of the most vital vehicles by which young people can be involved in God's work is a discovery of a spiritual gift. There is a unique God-given gift for all believing humanity to advance the cause of God. These divine enablements work through the ministry of the Holy Spirit for the building of the Church. The New Testament early Christian church was able to grow exponentially because leaders recognised and unearthed spiritual gifts among members (see 1 Corinthians 12:1-11). The spiritual gift inventory must be understood as asking each person the following questions, who are you? What makes you unique? What does God want you to do in

${ }^{26}$ Doug Fields. Purpose Driven Youth Ministries: 9 Essential Foundations for Healthy Growth (Grand Rapids: Zondervan, 1998), 210. life, and further unwrap your spiritual gift package and putting it on spotlight. So, Spiritual gifts are given to each person who in turn must work to compliment another one's gift to accomplish God's mission (see 1 Peter 4:10). A spiritual gift inventory must be conducted in each youth club. This will assist each young person in discovering a gift by which they can contribute to Church's mission and missional related activities. This test also assists leadership with placing young people in suitable positions and responsibilities that fit the personality.

\section{DISCIPLESHIP}

Mentorship helps young people to develop philosophy that promotes taking intentional steps towards being involved in Mission and to be disciples for Jesus. The gains of the program are a drive within young people to want to finish God's work by being co-workers with Him in the vineyard. Ellen White Echoes the same " with such an army of workers as youth, rightly trained, might furnish, how soon the message of a crucified, risen, and soon coming Savior might be carried to the whole world..." Counsels to Teachers, Parents and Students, p 555. This move does not only open doors to work for the Church or even salvation of others, but also entrench young people into the fundamental belief, which is the foundation of their faith. Mission is therefore faith building and faith building is mission. Commenting on the impact of mission of God's people, Wright says "the dynamic action of the kingdom of God in the words and the deeds of Jesus and the mission of his disciples changed lives, values and priorities, and presented a radical challenge to the fallen structures of power in society." ${ }^{27}$ Discipleship is about changing lives; it is about changing people's worldviews. Wright further comments, "To say Jesus is Lord, and not Caesar or any of his successors, is a major missional mandate in itself." ${ }^{28}$ Young people are called to this missional mandate as disciples for Christ in preparing a people and themselves for the kingdom.

\section{CONCLUSION}

It is imperative that the local church pays more attention to young people. This attention is definitely not a call for the church to organise events that will entertain young people. Entertaining events only deal with youth challenges temporarily. Programmes like mentorship and discipleship deal with many facets of youth related challenges and finally bring them to the cross of Jesus. The Church suffers the risk of losing youth if it does not implement a strategy of electing good leadership with capable mentoring skills into the department. The call for pastors and committee/board members to start caring for youth right at elections is long over due. True leadership must prevail by electing true leaders for young people who will implement mentorship programmes for young people. The benefits for mentorship

\footnotetext{
${ }^{27}$ C.J.H. Wright, Biblical Theology for the Mission of God's People: A Biblical Theology of the Church's Mission (Grand Rapids, MI: Zondervan, 2010), 42.

${ }^{28}$ Ibid., 43.
} 
programmes are two fold. Mentorship programmes help young people grow mentally and help with good decisionmaking. At the same time it builds a relationship with Jesus with translates to working for the salvation of others.

\section{REFERENCE LIST}

[1] Arzola. F. et al., Youth Ministry in the $21^{\text {st }}$ Century: Five Views (Grand Rapids: Baker Academic, 2015), 148.

[2] Blakeslee, Jennifer E. and Keller, Thomas E. "Mentoring: Building the Youth Mentoring Knowledge Base: Publishing Trends and Coauthorship Networks," Journal of Community Psychology Vol. 40 (September 2012): 845-859, accessed 17

[3] Coppedge, A. The Biblical Principles of Discipleship. Grand Rapids: Francis Asbury Press, 1989.

[4] Crosby, John C. "On the Importance of Mentorship," Accessed 18 July 2019, http://www.healio.com/journals/ortho/2009-4-324/\%7B3b54a1b2-a9fa-4d46-a6c2-a517f8b2dcb4\%7D/on- theimportance-of-mentorship.

[5] Earl, P. Mentoring. Renewal Journal. Discipleship, 11. Retrieved December 5, 2007, from www. pastornet.au

[6] Engstrom, Ted H., and Norman B. Rohrer, The Fine Art of Mentoring: Passing on to Others What God Has Given to You. Tennessee: Wolgemuth and Hyatt, 1989. Fields, D. Purpose Driven Youth Ministries: 9 Essential Foundations for Healthy Growth. Grand Rapids: Zondervan, 1998. Fernando Arzola et al., Youth Ministry in the 21 $1^{\text {st }}$ Century: Five Views. Grand Rapids: Baker Academic, 2015.

[7] Herman, L. from teaching to mentoring: Principle and Practice, dialogue and life in adult education. London: Routledge Falmer, 2004.
[8] Kram, K.E. Mentoring at Work: Developmental Relationships in Organizational Life (Glenview, IL: Scott Foresman, 1985.

[9] Lundin, Stephen. C. Harry Paul and John Christensen, Fish! A Remarkable Way to Boost Moral and Improve Results. London: Hodder and Stoughton, 2000.

[10] Mallison, J. Mentoring to develop disciples and leaders. Buckinghamshire, Buckinghamshire, UK: Scripture Union, 1998.

[11] Mbiti, J.S. African Religions and Philosophy, $2^{\text {nd }}$ Ed. (Heinemann Educational Publishers, 1969),

[12] Meyer, M. and Fourie, L. Mentoring and Coaching: Tools and Techniques for implementation. Randburg, South Africa: Knowres Publishing, 2004.

[13] Moore, W.B. Mentoring side by side: Mentoring in the Bible. Retrieved 5 December 2007, from www.mentoring-disciples .org

[14] Rhodes, J.E. "Youth Mentoring in Perspective," accessed 18 January 2016, http://www.infield.org/learningmentors/youth mentoring in perspective.htm.

[15] Shea, G.F. The Mentoring Organization. Menlo Park, CA: Crisp Publications, 2003.

[16] Stanley, P.D., and Clinton, R.C. Connecting: The Mentoring Relationship you need to succeed in life. Colorado Springs: Navpress, 1992.

[17] Steinmann, N. Fundamentals for Effective Mentoring: Raising giant killers. Randburg, South Africa: Knowres Publishing, 2006.

[18] White, E.G. Education. Mountain View, CA: Pacific Press, 1903. White, E.G. Patriarchs and Prophets. Washington, DC: Review and Herald, 1890.

[19] Write, W.C. Mentoring: The Promise of Relational Leadership (Waynesboro, GA: Paternoster Press, 2004), 137. Zachary, L.J. Creating Mentoring Culture: The Organizations Guide. San Francisco, Jossey-Bass, 2005. 